\title{
Study of Power and Dissidence in O'Neill's the Emperor Jones
}

\author{
Nafiseh Iranpour ${ }^{1, ~ *}$, Fatemeh Sadat Basirizadeh ${ }^{2, ~ * ~}$ \\ ${ }^{1}$ Al-Mustafa-University, Qom Branch, Qom, Iran \\ ${ }^{2}$ Researchers and Elite Club, Qom Branch, Islamic Azad University, Qom, Iran
}

Email address:

nafiseh.Iranpour@gmail.com (N. Iranpour),nbasiri2002@yahoo.com (F. S. Basirizadeh)

*Corresponding author

\section{To cite this article:}

Nafiseh Iranpour, Fatemeh Sadat Basirizadeh. Study of Power and Dissidence in O'Neill's the Emperor Jones. English Language, Literature \& Culture. Vol. 2, No. 4, 2017, pp. 37-44. doi: 10.11648/j.ellc.20170204.12

Received: July 18, 2017; Accepted: August 7, 2017; Published: August 23, 2017

\begin{abstract}
This Paper examines Eugene O’Neil's The Emperor Jones in Power and dissidence. O’Neill was highly under the influence and inspiration of his contemporary events and the traces of those events are reflected in his works. He prefers to deal with the authentic American types and backgrounds in his social dramas. The main characters of his plays under the tyranny of dominant power turn into dissidents and resist against the authority or control of the dominant system. They struggle to subvert the dominant order, and since they would be a threat for absolute power they are consequently condemned to harsh punishment. O'Neill in his selected plays represents the conflict between the marginalized group and the central one. His sympathetic tone indicates his intention in supporting the dissidence in social and political activities. In The Emperor Jones O'Neill scrutinizes the situations of the Afro-Americans and challenges the concept of power and authority in the White American ideology. Particularly in this play the interrelation of the dissident and dominant within a socio-cultural system is expressed.
\end{abstract}

Keywords: Cultural Materialism, Dissidence, Hegemony, Society and Environment, Allegiance, Power, Resistance

\section{Introduction}

This paper wants to examine Eugene O'Neill, The Emperor Jones (1920), based on Cultural Materialistic of power and dissidence viewpoint. According to this approach the text should be considered in its socio-economical context. The theorists of this critical approach argue that each literary text not only relates to its socio-economical and political contexts but also is highly under the influence of them. Thus for better comprehension of the literary texts the critic should pay enough attention to their cultural background. Cultural Materialists believe that the dominant system of the society imposes its own ideas on its member by means of hegemony. The governing system mutely captures the common sense and diverts the mind and ideology of the people in the direction of the dominant's purposes and allows no place for resistance. But always within a social system under the tyranny, discrimination and subordination of dominant power some part of the society like lower class, color-skinned, women and rural people are converted to the marginal division. Gradually the marginal group of society constructs the dissident part that wants to subvert the dominant order of the powerful state. The conflict between the dominant power of the society and the marginal group or dissident is represented in the literary works. The main task of a Cultural Materialist is to distinguish such struggle through reading of that text.

O'Neill in his plays represents the opposition between the groups of socio-political dissident and dominant. His main characters in these three plays are those who stand against the dominant order of the society and reject to be the social and political conformist. O'Neill argues that the dominant system of his society, i.e. Capitalism, legitimates all tyrannical processes within its realm of authority. Dominant system reacts against the militant resistance either by severe punishment or by keeping it marginal. He explores the effect of perverse social arrangement on both the oppressor and the exploited through the form, language and content of his plays. He shows the repression of entire people in modern 
time. In O'Neill's view the matter of dissidence could take place in various fields of human being; dissidence could be social, political, moral and psychological. The Emperor Jones also depicts through the expressionistic devices the story of an Afro-American who under the Whites' education turned to a dictator. The theme of The Emperor Jones leads us to the foreign policy of the United States in the Caribbean and the history of Americans' racial discrimination.

\section{Methodology}

Cultural Materialism is considered as a post-Structuralist approach because it aims to displace, deconstruct or even just somewhat to disrupt the previous delivery system. Cultural Materialism as a poststructuralist critical approach has been successful in displacing traditional humanist and formalist readings of literature with readings which pay attention to historical and political contexts, and more sensitive to the representation of oppressed and marginalized groups in literary and cultural debate. Cultural Materialism has also showed the extent to which conservative interpretations ignore the problems of race, gender and injustice in literary texts. Some part of Cultural Materialistic critical practice focuses on relating texts to the problem of representing 'the other'. This emphasis in Cultural Materialism has promoted the world of criticism and explores the representation of women, black authors and social marginality.

Contextual approaches were constructed after traditional approaches and New Criticism. Their background goes back to the nineteenth and early twentieth centuries when scholars asked to what extent literary texts were under the influence of the historical, political, economical, philosophical, religious and psychological contexts of their productions. One example of the contextual approaches was Marxist criticism which regards the production of literary texts as "the interface of material and socio-economical circumstances" (Selden 88). Class and economic structures were the particular focus of Marxist critics. Marxism views literature in terms of its relationship to society. Marxists critics study literature to examine how a literary work reinforces or undermines the current social structure. After the Second World War contextual approaches, especially Marxism, are considered as the outdated approaches. They have had a major comeback over the last two decades in approaches like New Historicism, Cultural Materialism and Cultural Studies. Thus, Cultural Materialism is somehow the revision of Marxism.

Some critics demonstrate that Cultural Materialism in studying of historical contexts of the literary works has objective method and belongs to Historicism. The delicate neglected point in this claim is the special viewpoint of Cultural Materialism towards the concept of history. Brannigan declares "Cultural Materialism announces that not only literature is shaped by history but also shapes it as well" (92). There is organic and inseparable relation between history and literature. The most famous concept of "the historicity of text and the textually of history" (Brannigan
195) in Cultural Materialistic theories reinforces this idea. Cultural Studies emphasize that any cultural phenomenon is valuable for serious analysis. Investigation of literature is one means to pursue Cultural Studies, but literature is no more important or significant culturally than other practices. There is no difference between literary works and other cultural products. Cultural Studies use the theories and methods of literary criticism to probe the depth culture both through the literary study and through the study of other texts or the cultural implications of popular culture.

The last important point about Cultural Materialism is the idea of how the condition of a text affects its reading. Cultural Materialism tries to understand the text in its form as materiality in the process of production and reception. The text for Sinfield is "incorporated in the power structures which comes to materiality; otherwise, it becomes marginalized outside the social structure" (Higgins 169). The manifestation of Cultural Materialism as a literary critical method actually refers to 1985 with cultural studies of a great British Marxist Critic, Raymond Williams. He was a member of Wales's working class who remained all his life deeply committed to his proletarian roots. His discussion is central to the formation of the emerging field of Cultural Studies in both England and The United States. Williams in one of his essays, Culture Is Ordinary (1958) states, "Latent within historical materialism is a way of understanding and diverse social and material production of works to which the connected but also changing categories of art have been historically applied. I call this position Cultural Materialism" (qtd in Higgin 54). Cultural Materialism literally consists of two key terms: Culture and Material. All cultural critics aim to define these two terms according to their cultural discourses. Jonathon Dollimore and Alan Sinfield in their book Political Shakespeare (1985) applied Raymond Williams's theory to a study of Shakespearian drama and defined its parameters in their own terms. They define cultural and material as the two fundamental concepts in Cultural Materialism. They point out that the cultural aspects of the theory combines two meanings: "the analytical term culture refers to social systems studied in anthropology and social sciences, and the evaluative term refers to art and literature as forms of high culture" (86). They also in describing the concept of culture argue: "In cultural Materialism, culture does imply a set of superior values, even a moral and ethical imperative, which provides the impetus behind its critical application to artifacts and practices which have been prized within the evaluative idea of culture" (24).

\section{The Variety of the Dissidents in the Emperor Jones}

The Emperor Jones represents the story of a black Pullman porter who under the Whites' education turns to a dictator of a West Island. Considering the style of the play, it is one of the expressionistic plays of Eugene O'Neill. Bayem argues: "More than any other dramatists, O'Neill brings the dramatic 
expressionism pioneered by Strindberg into the American canon" (457). He through expressionistic devices tries to make the audiences aware of the inner experiences of his characters. The Emperor Jones is a one-act play in eight scenes; the first and last scenes contain several characters and employ a realistic style while the six scenes in the middle are an expressionistic monologue chronicling Brutus Jones' nightmarish trip through forest. The language of the play is colloquial except of the scenes description. O'Neill pays no attention to the grammatical correctness of the words and sentences; he just writes the actual pronunciations of the characters to show that they are not fictional stereotypes, but rather they are lifelike individuals. He by use of language and scene designs provides the expressionistic mood in his play; for example, in the scene description of Scene Two he states: "A somber monotone of wind lost in the leaves moans in the air. Yet this sound serves but to intensify the impression of the forest's relentless immobility, to form a background throwing into relief its brooding, implacable silence" (Scene II 229). Travis Bogard observes:

Technical excitement of the play with its drums, its sustained monologue, its rapidly shifting settings framed into a single desperate action were almost blinding in their virtuosity and in their assurance of important theatrical things to come. Not only the literate American Drama, but the American theatre came of age with this play. (134)

The main themes of The Emperor Jones are racism in the American society and the concept of Empire in O'Neill's ideology. O'Neill challenges the White authority and brings the concept of the Empire under question. Michael Manheim in his book says: "The play calls attention to the racial oppression that actually existed in America in 1920" (183). In O'Neill's contemporary society the white people were dominant and the colored skinned persons who received discrimination from the dominant structure were subordinates. In Scene One Smithers, the white cockney trader, expresses skepticism over Jones' claim that he killed a white man before coming to the island: "from what I've heard, it ain't 'ealthy for a black to kill a white man in the states. They burn 'em in oil, don't dey?" (220). Smither as a white man clearly represents the racist attitudes that were present in O'Neill's contemporary society. Sometimes Smithers reveals his racism somewhat subtly as in the opening moments of the play when he assumes that the peasant black woman sneaking through the throne room must have been "stealing a bit" (218). In the last scene of the play he also considers all dark-skinned people as "stupid as 'ogs, the lot of "em! Blasted niggers!" (245).

O'Neill in this play challenges the concept of Empire. He regards that being powerful had been one of the great dreams of all human being throughout history. Virginia Floyd in her book, Eugene O'Neill at Work (1981), declares that "In O'Neill's viewpoint man's social affairs and ambitions for social reform seem just as a disguise for a will to power" (240). O'Neill opposes the established discourse of modern period which reinforces the supremacy and legitimacy of the White's authority. In the beginning of the modern period some philosophers like Frederic Hegel (1770-1831) put forward the imperialistic ideas that: "empire is the white man's burden" (qtd in Takeuchi 88). They wanted to advertise their false idea that just the whites can take the responsibility of the absolute power. Under such situation it seems impossible that the colored-skinned citizens could become powerful dominant. Moreover, the other fact that affects O'Neill's attitudes toward the concept of power relates to the position of the United States in the world. The turn of the twentieth century witnessed the emergence of the United States as the first-rate power of the world. Manheim holds "The United States' defeat of long-time colonial power Spain in 1898 solidified its own status as an imperial power" (100). O'Neill doesn't agree with the imperialistic goals of his country, and prefers to act against it. Therefore, he deliberately sets a black man as an Empire with tragic destiny in order to overthrow the modernist philosophy and to despise the unrelieved imperialistic strategy of the United States. O'Neill assumes empire or possession of absolute power is unremarkable issue. The concept of empire seems negative connotation in O'Neill's ideology. In Scene one he clearly stresses his attitude toward the concept of power when Brutus says "dere's little stealing, like you [Smithers] does, and dere's big stealing like I does. For de little stealing dey gits you in jail soon or late. For de big stealing dey makes you Emperor and puts you in de Hall o' Fame when you croaks" (221).

Some contextual critics investigating the historical, social and political contexts of O'Neill's plays argue that the figure of Brutus Jones was suggested by a character of a bartender who O'Neill had known. Michael Manheim insist, however, that O'Neill has based the fall of Jones on that of "Haitian Emperor Henri I (Henry Christopher Sam), except that he committed suicide with a silver bullet when he was about to be captured by rebellions" (98). Moreover, John Gessner assumes another background for the play: "a prospecting expedition to Honduras in 1909 had caused O'Neill became interested in the deep jungles, and his acquaintance with the beating of tom-tom suggested the idea of drum beat used throughout the play" (97). Among the contextual critics Cultural Materialists aim to clarify the marginal types of the dominant system of O'Neill's plays and to evaluate the attitude of O'Neill toward them. In O'Neill's society the nonwhite people are considered as the marginal figures that deserve subordination. O'Neill by writing The Emperor Jones challenges the fundamental established ideas of his time; he for the first time places a black man as a central character of the American stage and represents him in the position of an emperor; that was improper in his time, and made his racist audiences angry. Diya M. Abdo in his article, The Emperor Jones: A Struggle for Individuality, pointes out that "O'Neill intentionally shows that Jones is Smithers' superior both physically and intellectually" (12). Jones is "powerfully built, full-blooded" (218), and possesses "an underlying strength of will [in his face], a hardy, self-reliant confidence in himself that inspires respect" (219). Smithers is by contrast drunken, "stoop-shouldered, sickly yellow" 
(217). It is not simply the physical appearance which makes Jones the superior; he is intellectually higher than Smithers. Jones is "alive with a keen, cunning intelligence" while Smithers is "cowardly and dangerous" (217). Moreover, O'Neill challenges the prevalent conception of blacks as passive, idle and lazy: “and ain't I got to learn deir lingo and teach some of dem English befo' I kin talk to 'em?" (220). More than intelligence, O'Neill gives Jones the drive and the desire to be the best he can be; and he succeeds in two years to become Emperor of the island, not just through hard work but a great deal of intelligence and ingenuity. Naturally O'Neill's unorthodox task to put valuation on the marginal blacks is not the dominant's desire.

In Emperor Jones we inter to the mind of the characters that is to say the whole theater is in the mind of the characters on the one hand they have the performance of the play on the other hand they have participation of the audience in the course of the incidents and what we see. Emperor Jones hides himself behind that silver bullet and authority makes the indigenous people.

If you consider Jones as a colonizer. Well you can refer back to Hegelian argument between lord and slave that is to say the colonizer encounters the colonized tradition and cannot over time the tradition. That is the colonize values the colonize codes, cultural and social codes. Jones must die colonizer is defeated by indigenous traditions. In addition I find master morality base on action good and bad but slave morality base on action good and evil. Thinks are quite different talks about the most prominent respectable we can say silver bullet as politics and superstition as power. Jones enters in the forest and moves through different way one of the point refer to discourses, by means of discourses and pattern of understanding people in period will understand the universe the world around themselves that change from one period to the next one. Hence in every culture discourse is what a superstition that impose and injected the life in mind of people and way of thinking and understanding of them. Individual life of people could be consider as machine without driver moves continually it moves forward and every individual is a practitioner of the work of power. When you have resistance you have power. The sound of Tom Tom: show this primitivism more and more. Related to European colonization of nonwestern countries in that way consider the none European as uncivilized this form is originated in western philosophy man and woman. Base on this superiority and colonizing they consider European as masculine and none European other uncivilized savage feminism. This a political construction and in reality doesn't exist. Power compare with machine it doesn't need driver it means Hegemony.

1. First Jones enters Island.

2. Power stretch in different ways though different means or signs and different discourses

Jones with a laugh oh, that silver bullet!... (4). Jones by means of such superstition imposes Anthology. Jones is mentally disintegrated and mentally is dead. Through play we understand Jones is a murder and makes native accept him as someone come from heaven and immortal. How am I? That is important why I is? The way O'Neil unhinges language. He wants the other accept him as what he wants. Finlay native believe Jones and be killed by silver bullet. When the moment Jon's enters to the forest no longer is himself, he is controlled by Tom Tom.

\subsection{Cultural Materialism in Emperor Jones}

One of aims of the Cultural Materialists is to distinguish the influence of the contemporary situations of playwright's time on his works. There is a proof which shows the contemporary socio-economical conditions of O'Neill's time affecting his play: "In 1900s Africans, Latin Americans and Caribbean migrated to North America due to war, political persecution and economical difficulties" (Shiply 68). This historical matter inspires O'Neill and constructs in his mind a background for composing the play. But we see O'Neill as a creative artist looks at the main concern of his time from innovative viewpoint. He in The Emperor Jones, instead of reflecting the current subject of his time i.e. migration to America, contrarily depicts the migration of an AfroAmerican to a Caribbean Island in order to prepare a new and unorthodox view to a realistic matter. Although O'Neill is highly affected by his contemporary events, he never neglects his artistic creation for the sake of expressing social reality. Thus, The Emperor Jones with realistic foundation is decorated by artistic imagination like expressionistic devices and stands as a more complex work of O'Neill.

One of the basic elements of expressionism that is significant in The Emperor Jones is color. Color has symbolic meanings in the expressionistic dramatic works and is linked to the subjectivity of the artist in order to express his inner thoughts. In this play O'Neill uses the color white; white is everywhere in the imperial palace as the introductory stage direction makes clear: "the audience chamber in the palace of the Emperor- a spacious, high-ceilinged room with bare, whitewashed walls. The floor is of white tiles. In the rear, to the left of the center, a wide archway giving out on a portico with white pillars" (217). David Krasner asserts that the color is meant to represent "Jones's belief in the superiority of the white man; black himself, Jones attempts to intimidate his black subjects with the whiteness that actually intimidates, for, though black-skinned, he is fully white in his way" (152).

On the contrary, the forest into which he flees is described in the first stage direction of Scene Two as "a wall of darkness that dividing the world" (229). There he searches for a white stone that marks the place where food has been buried: "white stones, white stones, where is you?" (230), but he is shocked to see not one but many of such stones: "but how come all dese white stones? And what's dat tin box o' grub I hide all wrapped up in the oil-cloth?" (230). Krasner explains: "Hence, whereas the whiteness he had earlier wanted to appropriate fails him now and reveals his authentic nature as both a political and racial usurper, the blackness of the jungle engulfs him in a mortal embrace" (155). Jones's journey is from the whiteness that wraps him up in his palace 
into the darkness of his inner personality. The contrast between his white civilized exterior and black savage interior never reaches to the stable harmony.

Beside aesthetic aspects of The Emperor Jones O'Neill reveals some realistic aspects that had occupied his thoughts. One of these points is the influence of the dominant White ideology on the mind of all members of society even the marginal colored-skin persons; in the passage that Jones declares his idea about power O'Neill stresses clearly that Brutus had been under the white's education and had learned the strategy of governing from them: "If dey's one thing I learn in ten years on de Pullman ca's listenin' to de white quality talk. And when I gits a chance to use it I winds up Emperor in two years" (221). Gessner contends, "When Brutus came in power he actually followed the white's pattern of tyrannical ruling" (156). If there is blame on Jones for his oppression over natives, again it should refer to the white's ideology.

\subsection{The Socio-economic Context of Emperor Jones}

Jones as an Afro-American is the amalgamation of two cultures: African and American. When Brutus Jones is considered within the American society, he is classified as dissident, and the whole system of American society as the dominant. But when he is considered as an Emperor in the Caribbean Island, he is dominant, and the rebellion natives are dissidents. Therefore, there are various types of dissident and dominant in this play, and the shift of dissident/dominant function for Brutus Jones is very interesting. The only criterion for the shift of function is accepted American culture. As soon as Jones obeys his American culture he changes to a tyrant and profiteer, and when he wants to be African he is condemned to be subordinated. O'Neill through the expressionistic journey of the forest gradually wants to reconcile Jones with his ancestral culture. The black slaves in the ship in Scene Six, the auctioneer in Scene Five, the black prisoners in Scene Four and the Congo witch-doctor in Scene Seven attempt to awake Jones particularly and all AfroAmericans generally. Bogard discusses: "Jones's acts of will, his pride, and his conscious individuality as Emperor are the false masks of a white savage" (141).

Most critics tend to characterize Jones as a rebellious and treacherous member of his community to which he must ultimately submit. Their idea is not thoroughly true, since they neglect the difference between the Afro-American and the Afro-Caribbean. Jones is an Afro-American who oppressed the Afro-Caribbean in his Empire. The distinction between them is very important. David Rodgers in his $A$ Critical Commentary on the Plays of Eugene O'Neill declares:

Although they have a common ethnic background, the racial experience of the two groups was not identical: they do not speak the same language nor do they share the same cultural or religious attitudes. Thus there is no sympathy between them, and Jones considers the native Islanders as the outsiders and vice versa. (64)

The Emperor Jones is the performance of the destruction of an Afro-American by two conflicting impulses in Jones's nature. He is in doubt whether he is African or American. His physical appearance (dark skinned) forces him to accept his inferiority in the White civilization and at the same time his thought and his ambition to overcome the White's racial discrimination direct him to behave like an American. In searching for identity, Jones has had two choices that both led him toward the tragic destiny. One option was to be African and the other one was to be American. If Jones had accepted to be faithful to his race, he remained the marginal, oppressed Pullman porter in his environment. But if he had chosen the second option and had accepted to adopt the white American civilization which made him central and powerful, he would have been accused as a traitor to his race and to the colonized natives. Jones deliberately selected the second way and accepted the American identity in order to avoid being oppressed, and to provide a different perspective on AfroAmericans situation.

Martin Summers stresses that the black men experienced their race identities "solely in relation to their social, economical and political marginalization" (Summers 15). One way in which social constructionists address race and ethnicity is a theoretical framework of Hegemony. According to Antonio Gramsci's theory, a ruling group wields power in order to illustrate the power relationships that are constitutive of the social construction of racism. Hegemonic racism could be defined as the "configuration of race practice which embodies the legitimacy of the governing which guarantees (or is taken to guarantee) the dominant position of white and subordination of black" (Ibid16). In addition to structuring the relations of dominance/ subordination between white and black, hegemonic racism puts value on the neglected issues of power such as the hidden collusion of dominant and dissident in order to reinforce the absolute power of dominant. However, by reducing race identity to the expression of power, it threatens to render marginalized social groups invisible, or it allows them visibility only to the extent that they validate hegemonic racism.

Hegemonic racism or the dominant cultural ideals of the supremacy of whites over blacks becomes the terrain on which the marginalized and subordinated parts of the society are constructed and performed. However, the relationship between dominant and subordinate in cultural hegemony is not always one of antagonism. Always there is the influence of the marginalized ethnic and racial groups on the culturally dominant ethnic and racial conventions. As Raymond Williams stresses, hegemony "does not just passively exist as a form of dominance, rather it has continually to be renewed, recreated, defended and modified. It is also continually resisted, limited, altered and challenged by pressures not at all its own" (qtd in Wilson 29). O'Neill also shows the smooth harmony between Smithers and Jones within the American hegemony. In Scene One Smithers emphasizes that he had assisted Jones to become Emperor: "well, blimey, I give yer a start, didn't I-when no one else would" (220), and Jones asserts instead of him that "I done de dirty work fo' you-and most of the brain work, too, fo' dat matter-and I was 
wu'th money to you' (220).

The initial description of the location of The Emperor Jones could be the evidence of O'Neill's political agenda to reveal the colonizing face of the United States: "the action of the play takes place on an island in the West Indies as yet not self-determined by White Mariners. The form of the native government is, for the time being, an Empire" (216). O'Neill by self-determination intends the determination by the United States military power. J. W. Krutch states that this description suggests: The play is not only a fiercely problematic staging of race, but also it is a play about the possibility of AfricanAmerican self-determination. By making Jones a Pullman porter, O'Neill identified a powerful presence in the United States' culture that is to become a force in the early Civil Rights movement. (64)

O'Neill by the forest journey makes clear the inter relationship between the past and present of each person. Manheim holds that "O'Neill wants to say that a writer could not write about the present but only about past that was far enough back in time to be seen with some degree of wholeness and coherence" (167). The forest is not just a place where something happens to Jones; it is part of what that had happened to him before and had shaped his personality, his culture and his civilization.

In Fourth Scene, the forest at "the end of the plain... a wall of darkness dividing the world" (229) symbolizes the dark history of Jones's race that through it Jones remembers the long-time oppression over his ancestors. He in his journey to the forest always relies on his silver bullet and just that bullet gives him strength to confront with the strange scenes of the forest. Bogard maintains that "Jones's silver bullet stands for his ultimate refusal to submit to any social sanction which might be imposed on him by the natives of the island if they caught him" (qtd in Abdo 25). Thus, Jones could be considered as a nonconformist to his environment "I kill you, you white debil, if it's de last thing I evah does!" (236).

Jones is a black man who wants to show to the whites that he is a "free Nigger" (Scene V 238); but this contradictory wish in the 1920s American society is exactly impossible. He is doomed to leave the political activity. O'Neill very smoothly depicts that in the American context a black man cannot escape the burden of pain and the memory of slavery which have been passed on from one generation to the next. At the end of the play we see Jones looks very much like a slave, "his pants have so torn away that what is left of them is no better than a breach cloth" (239).

There is another perspective, as mentioned before, that considers Jones as dominant and the West Indies Islanders as dissidents. They aim to put an end to Jones's dictatorship. The idea of rebellion against the tyrannical status quo is intensified by the use of the theatrical devices. Doris Falk declares 'O'Neill's use of the tom-tom beating first at the rate of normal pulse, and then gradually faster until it stops at the moment of Jones's death implies the process of resistance" (93) against the dominant structure, as we see in Scene six that he describes the drum beat: "louder, quicker, with a more insistent, triumphant pulsation" (240) that implies the final victory of the native drum beaters in arresting Brutus Jones.

Some critics maintain that beyond the story of a Pullman Porter who turns to a dictator lay a germ of O'Neill's idea for "a tragic romance of American history" (Krasner 149). Krasner argues:

The hero of the play is an Afro-American corrupted by the mercantile mentality of the Whites who had enslaved his ancestors and his flight from the natives on his West Indian Island would symbolize a disintegration culture confronting again the forest primeval that had always haunted its dreams. (156)

What is significant in The Emperor Jones is that his journey on stage is one into history, a flight backward in time toward the uncovering of the original sin that, in O'Neill's view, is slavery: "the possession of those who cleared the wilderness as well as of the wilderness itself" (Dusenbury 120). In this respect, then, O'Neill is not exploring in The Emperor Jones the collective unconscious of the American Negro so much as he is exploring the collective conscience of Americans. Therefore, The Emperor Jones explores the nature of White American past.

\section{Conclusion}

O'Neill in his dramatic works tries to depict the complex mental disturbance of modern man. He, contrary to the traditional dramatists who want to represent the tragic destiny of those who are not in harmony with God or with universe, attempts to convey the harsh situation of those who are not in harmony with other human beings. In traditional and classical dramas the conflict had been between metaphysical forces and a human being, but in modern drama especially in O'Neill's drama the conflict exists between human species. In modern time one part of society assumes itself as the possessors of all powers of the world and legitimizes the oppression and tyranny over the other part of the society. One of the critical movements which are constructed in relation to the deplorable situation of the marginal part of the society is Cultural Materialism. Cultural materialism tries to observe the interaction between State power and cultural forms, and how the theatre has been used as a prime location for the representation of power. For Cultural Materialism the concept of power implies the object of struggle. Cultural materialists define the alien and unruly individuals as 'Other'. The existence of 'Other' is allowed only as evidence of the rightness of established power. Critics like Dollimore and Sinfield argue that the resistance or subversion may indeed be appropriated by authority for its own purpose, but it can be used against authority as well as used by it. Thus, the demonized elements in modernist culture, the subordinate, the marginalized and the dissidents are identified as the forces to be self-identified. In Cultural Materialism the process of resistance is the outcome of the struggle between marginality and power. The social, political, cultural and economical aspects of O'Neill's contemporary society had affected highly his plays. Some critics 
categorized his entire plays that all of them at least contain dual aspects: first those peculiar features which are limited to American life and thought, and second those feature that are not limited by either time or place and are rooted in the universal experiences of mankind. In the selected plays studied in the thesis all of those features are illustrated, but Cultural Materialists in their critical investigations are more concerned with the first type features.

O'Neill's tone in The Emperor Jones indicates that he is a supporter of the dissidence in the social and political activities. His tone is sympathetic to the plight of the modern characters that are marginalized, victimized and enslaved by the social class and by the established rules of the dominant system. O'Neill as an attentive dramatist to his socio-political context depicts the ugly picture of the dominant American governing system. The struggle of his central characters represents the debilitating effects of the crashing forces of the capitalistic economic system upon the human character. The setting of The Emperor Jones is the Caribbean Island which somehow is unknown and mysterious place for Americans. Its deep forest and surrounding oceans increase its strangeness. O'Neill based on his intended meaning, which is the improbable condition that an Afro-American can become an Emperor, prefers to set a Caribbean Island, or in his term a far-away land, as his play's setting. O'Neill by his setting satisfies the audiences of 1910s who legitimated the racial discrimination. He also proposes his justification for his presumptuousness to put a Blackman as his central character. For his citizens it is impossible that a black could be an Emperor. For them the blacks are always subordinate. O'Neill indirectly shows that this matter just could be possible in the remote place. Time is not important in The Emperor Jones because there is no beginning or end for racism in the United States. In order to indicate time he just mentions night, downfall, morning, etc. which shows the intensity of racism in the American history. Through night voyage the various locations appear in front of Brutus Jones that each of them refers to one epoch of the history that the harsh oppression and discrimination exist in it significantly. Jones is an embodiment of that original violation of America's communal spirit, the introduction of slavery (the vilest manifestation of the profit motive) to a fresh and vital land. In O'Neill's eyes he is both victim and victimizer for he has reenacted that original violation by enslaving the natives of his West Indies Empire. He has tried to redeem his wounded selfhood by adopting the mask of his oppressors, but in thus attempting to possess his soul he has corrupted the vital force sustaining it beyond redemption.

\section{References}

[1] Abrams, M. H. A Glossary of Literary Terms. New York: Harcourt Brace Pub, 1993. Barker, Chris. Cultural Studies: Theory and Practice. London: Sage publication Inc, 2004.

[2] Barler, Chris. Sage Dictionary of Cultural Studies. London: Sage Pub Inc, 2003. Barry, Peter. Beginning Theory, an
Introduction to Literary and CulturalTheory. New York: St. Martin press, 1995.

[3] Bayem, Nina, ed. The Norton Anthology of American Literature. $4^{\text {th }}$ ed. New York: Norton press, 1994.

[4] Bigspy, C. W. E. A Critical Introduction to Twentieth Century American Dramas. New York: Cambridge press, 1984.

[5] Bogard, Travis. Contour in Time: The Plays of Eugene O'Neill. New York: Oxford UP, 1972.

[6] Brannigan, John. New Historicism and Cultural Materialism. New York: ST. Martin press, 1998.

[7] Brustein, Robert Sarford. The Theatre of Revolt. New York: Atlantic Monthly press, 1927.

[8] Clark, Barrett. Eugene O'Neill: The Man and His Play. New York: McBride Company, 1929.

[9] Day, Cyrus, ed. The Twentieth Century Interpretations of the Iceman Cometh. New York: Englewood Cliffs Pub, 1968.

[10] Dollimore, J. and Sinfield, A. Political Shakespeare: Essays in Cultural Materialism. London: Manchester University Press, 1994.

[11] Dusenbury, Winifred. The Theme of Loneliness in Modern American Drama. New York: Gainesvildge Pub, 1960.

[12] Falk, Doris. O'Neill and Tragic Tension: An Interpretive Study of the Plays. New York: Rutgers UP, 1985.

[13] Floyd, Virginia. Eugene O'Neill at Work. New York: Ungar Pub, 1981. Gelb, Arthur. Nine Plays of Eugene O'Neill. New York: Random House, 1954. Gessner, John. ed. Eugene O'Neill: A Collection of Critical Essays. New York: Englewood Cliffs, 1946.

[14] Higgins, John. Raymond Williams, Literature, Marxism and Cultural Materialism. New York: Routledge Press, 1999.

[15] Krasner, David. ed. A Companion to Twentieth Century American Drama. New York: Blackwell Pub, 2005.

[16] Krutch, Joseph Wood. American Drama Since 1918. New York: Addison-Wesely Publishing Company, 1957.

[17] Lewis, Allan. American Plays and Playwrights of Contemporary Theatre. New York: Crown Pub, 1965.

[18] Lodge, David, ed. Modern Criticism and Theory. New York: Longman Pub, 2000. Lonely, Glenn Meredith. Twentieth Century Theatre. New York: Facts\& File Publication, 1983.

[19] Makaryk, Ireana. Encyclopedia of Contemporary Literary Theory: Approaches, Scholars, Terms. Toronto: Toronto university Press, 1993.

[20] Manheim, Micheal. ed. The Cambridge Companion to Eugene O'Neill. New York: Cambridge UP, 1998.

[21] Maufort, Marc. ed. Eugene O'Neill and the Emergence of American Drama. Amesterdam: Rodopi Pub, 1989.

[22] Murphy, Martin. Cultural Materialism, Study/ Culture. New York: University of Florida, 1995.

[23] Newton, K. M. Twentieth Century Literary Theory. New York, 1995. Nugent, Elizabeth. The Iceman Cometh: A Critique. New York: Monarch Press, 1965. Prendergast, Christopher. ed. Cultural Materialism: On Raymond Williams. New York: Minnesota University Press, 1995. 
[24] Rodgers, David. The Plays of Eugene O'Neill: A Critical Commentary. New York: Monarch Press, 1965.

[25] Selden, Roman. Contemporary Literary Theory. London: Harvester Wheatheaf, 1993. Shipley, Joseph. Guide to Great Plays. Washington D. C.: Public Affairs Press, 1956. Stansell, Christian. American Moderns: Bohemian New York and the Creation of a New Century. New York: Blackwell Pub, 1999.

[26] Summers, Martin. Manliness and its Discontents: The Black Middle Class and the Transformation of Masculinity, 19001930. New York: North Caroline UP, 2000.
[27] Takeuchi, Y. The Theory of Culture. Tokyo: Iwanmi, 1981. Wilson, Scott. Cultural Materialism, Theory and Practice. New York: Blackwell Pub, 1995.

[28] Wilson, R. and Dutton, R. ed. New Historicism and Renaissance Drama. New York: Longman press, 1992.

[29] Abdo, Diya. The Emperor Jones: A Struggle for Individuality. Wilkins, Fredrick. ed. The Eugene O'Neill Review: volume 24, No I\& II. Spring-Fall 2000.1/5/2004. 